Система В. О. Сухомлинського привертає увагу ціннісною спрямованістю на пошану до кожної дитини, розумінням іiі самобутності й унікальності. Під плином вимог сучасного життя вона, безперечно, постійно трансформується. Проте принципова основа залишається майже незмінною. Серед відомих систем виховання вона виокремлюється як «найгуманніша педагогіка», і потребує грунтовного вивчення й використання у процесі реалізації освітніх реформ, насамперед у ході розбудови Нової української школи.

\section{СПИСОК ВИКОРИСТАНОЇ ЛІТРАТУРИ}

1. Концепція «Нова українська школа» [Електронний pecypc]. URL: http://mon.gov.ua/activity/ education/zagalna-serednya/ua-sch-2016 (дата звернення: 20.06.2019).

2. Концепція реалізації державної політики у сфері реформування загальної середньої освіти «Нова українська школа» на період до 2029 року від 14.12.2016 № 988-p. [Електронний ресурс]. URL : http://www.kmu.gov.ua/control/uk/cardnpd?docid= 249613934 (дата звернення: 27.07.2019).

3. Закон України «Про освіту» від 05.09.2017 № 2145-VIII [Електронний ресурс] // Відомості Верховної Ради. - 2017. - № 38-39. - C. 380. URL: https://zakon.rada.gov.ua/laws/show/2145-19/print (дата звернення: 20.06.2019).

УДК 378.14.015.62

DOI: 10.37026/2520-6427-2019-99-3-152-157
4. Калініченко Н. А. Гуманістична спрямованість підготовки майбутніх учителів природничих наук / Н. А. Калініченко // Наукові записки ; ред. кол. : В. Ф. Черкасов, В. В. Радул, Н. С. Савченко та ін. Кропивницький : Код, 2018. Вип. 171. - С. 54-59. (Серія «Педагогічні науки»).

5. Калініченко Н. А. Навчання обдарованих учнів у дидактичній системі Василя Сухомлинського / Н. А. Калініченко // Науковий вісник Миколаївського нац. ун-ту ім. В. О. Сухомлинського. Педагогічні науки : зб. наук. пр. / за ред. Т. Степанової. - 2018. Т. 1. - № 3 (62). - Миколаїв : МНУ імені В. О. Сухомлинського, 2018. - С. 71-76.

6. Сухомлинський В. О. Розмова з молодим директором / В. О. Сухомлинський // Вибрані твори : в 5 т. - К. : Рад. школа, 1976. - Т. 4. -640 с.

7. Сухомлинський В. О. Сто порад учителеві / В. О. Сухомлинський. - К. : Рад. шк., 1988. - 310 с.

8. Сухомлинський В. О. Методика виховання колективу / В. О. Сухомлинський // Вибрані твори : в 5 т. К.: Рад. шк., 1976. - Т. 1. - С. 403-637.

9. Сухомлинський В. О. Павлиська середня школа / В. О. Сухомлинський // Вибрані твори : в 5 т. - К. : Рад. шк., 1977. - Т. 4. - С. 5-390.

Дата надходження до редакиіï: 11.08.2019 p.

Інеса ХМЕЛЯР, кандидатка педагогічних наук, професорка кафедри хіміко-фармацевтичних дисииплін КЗВО «Рівненська медична академія»

Рівненської обласної ради

Оксана МялЮк, кандидатка біологічних наук, завідувачка навчально-методичною лабораторією, викладачка клінічної лабораторної діагностики КЗВО «Рівненська медична академія» Рівненської обласної ради

\title{
ФОРМУВАННЯ ДОСЛІДНИЦЬКОЇ КОМПЕТЕНТНОСТІ СТУДЕНТІВ-ЛАБОРАНТІВ
}

У статті обтрунтовано підходи до визначення змісту дослідницької компетентності студентів, визначено ефективні форми, методи і засоби ї̈ формування у прочесі викладання навчальної дисципліни «Клінічна лабораторна діагностика». Представлено пріоритетні освітні технології та методи, які не надають готових знань, а спонукають до пошуку, та в яких роль викладача зводиться до функиії тьютора й організатора, щзо сприяє підвищенню самооиінки особистості студента, закладає основи його професійного зростання. 3'ясовано структуру та етапи проведення практичних занять із навчальної дисичпліни «Клінічна лабораторна діагностика».

Ключові слова: дослідницька компетентність, дослідницькі вміння, професійна підготовка майбутніх лаборантів клінічних лабораторій.

В статье обоснованы подходы к определению содержсания исследовательской компетентности студентов, определены эффективные формы, методы и средства ее формирования в прочессе преподавания учебной дисииплинь «Клиническая лабораторная 
диагностика». Представлены приоритетные образовательные технологии и методы, которые не дают готовых знаний, а побуждают к поиску, в которых роль преподавателя сводится к функичи тьютора и организатора, что способствует повышению самооценки личности студента, закладывает основы его профессионального роста. Выяснено структуру и этапь проведения практических занятий из учебной дисииплины «Клиническая лабораторная диагностика».

Ключевые слова: исследовательская компетентность, исследовательские умения, профессиональная подготовка будущих лаборантов клинических лабораторий.

The analysis of the European experience in the training of medical professionals in recent decades has substantiated the ways of reforming medical education in Ukraine. It is becoming apparent that an integrative approach should be the result of scientific explorations of improvement the educational process of higher education in medical institutions. Therefore, approaches to the content of the professional education of laboratory students involve the availability of ground knowledge and skills in professionally oriented disciplines that lay the foundations of clinical thinking. Therefore, they should be informed, competent, competitive, capable of self-improvement. The organization of educational activity of a higher education institution should be oriented to the formation of competencies of students to let them self-studying.

The article grounds approaches to determining the content of research competence of laboratory assistants students, it defines the effective forms, methods and means of its formation in the course of teaching the discipline "Clinical Laboratory Diagnostics». Future medical laboratory students must have up-to-date clinical research techniques, various forms of work organization in the field of laboratory diagnostics, be familiar with modern methods of detecting pathological processes of different systems and organs, and must be able to organize laboratory studies in accordance with all regulatory requirements. Therefore, the main components of our research competence include: informational one - the ability to search information, to find information in a book, directories and other sources or technical sources of information; creative one - the ability to generate ideas, hypothesize research; ability to analyze, synthesize and summarize information, to systematize and classify it, to identify contradictions, to carry out retrospective analysis. Formed research competences contribute to the formation of active, mobile future specialists of clinical laboratory diagnostics who will move forward, will be able to plan, organize, adequately evaluate the results of their own professional activity. The following structure should be followed when conducting practical classes: the stage of motivation, determination and planning; the stage of input diagnostics of the level of knowledge and skills; educational stage; control and correction stage.

Pedagogical conditions such as the development of learning motivation, the definition of goals and expected results, and the use of interactive technologies play an important role in the formation of research activities of medical students. The consideration of certain pedagogical conditions occurs in the course of conducting a competently oriented lesson. While preparing for the lesson a teacher should:
- use demonstration and didactic material, taking into account the individuality of each student, to encourage them to self-studying under the guidance of the teacher;

- apply forms and methods of control and self-control of students' educational activity;

- use interactive teaching techniques that develop interest in research.

The specified approach to the organization of educational activity of the medical student contributes to the increase of self-esteem and causes the desire for self-improvement, which is the basis for the formation of research competence.

Key words: research competence, research skills, professional training of future laboratory students of clinical laboratories.

У сучасних умовах розвитку суспільства зростають вимоги до професійної компетентності медичних працівників. Урахування прогресивних ідей досвіду підготовки спеціалістів медичної галузі за останні десятиліття зумовили реформування медичної освіти та відповідні зміни в доктринах, концепціях і моделях підготовки студентів-медиків. Стає очевидним, що результатом наукових розвідок щодо пошуків удосконалення освітнього процесу медичних закладів вищої освіти має стати інтегративний підхід. Нові підходи до змісту професійної освіти студентів-лаборантів передбачають наявність грунтовних знань та вмінь із професійно зорієнтованих дисциплін, які формують основи клінічного мислення. Сучасному медичному працівнику необхідно швидко орієнтуватися в бурхливому потоці інформації, визначати проблеми та вчасно знаходити шляхи їх розв'язання. Зважаючи на це, вони мають бути поінформованими, компетентними, конкурентоспроможними, здатними до самостійного вдосконалення. Тому організація освітньої діяльності повинна бути зорієнтована не лише на засвоєння готової інформації та подальше іiї відтворення, але й на формування вміння здобувати знання самостійно.

Отже, освіта потребує свого вдосконалення, що базується на компетентнісному підході до організації освітнього процесу, на що і вказують нормативно-правові документи, які регламентують діяльність вищої школи.

Незважаючи на значний інтерес науковців до пошуку шляхів формування дослідницької компетентності майбутніх фахівців різного профілю, проблема впровадження компетентнісного підходу в медичних закладах вищої освіти є розробленою недостатньо.

Аналіз наукових досліджень і публікацій. Теоретичний аналіз наукових поглядів на сутність та структуру дослідницьких умінь і навичок студентів дозволив виявити різноманітність підходів щодо цього питання. Впровадженню компетентнісного підходу до організації освітнього процесу у ЗВО приділяла увагу значна кількість науковців, зокрема організації самостійної діяльності студентів - А. Алексюк, К. Бабенко, В. Буряк, Н. Греков, М. Князян, П. Підкасистий. Особливості формування дослідницьких умінь у студентів медичних коледжів висвітлені в напрацюваннях I. Губенко, О. Гуменюк, В. Лазоришинця, М. Дем'янчук, Л. Симонович, І. Хмеляр, М. Шегедин. На розвитку дослідницьких умінь під час виконання лабораторного практикуму закцентовано увагу в студіях Л. Гольдіна, К. Кортнева та ін. Про особливості застосування під час навчання віртуальних експериментів йдеться в роботах О. Чорного, 
Д. Родькіна, А. Васильєва. Значення інформаційно-комунікативних технологій для формування дослідницьких умінь досліджували С. Раков, Ю. Триус, О. Каневська та ін.

Однак, узагальнивши вищеозначені дослідження, зазначимо, що методологічні підходи до формування дослідницьких умінь студентів-лаборантів не знайшли належного обгрунтування.

Мета статті полягає у визначенні науково обгрунтованих підходів до встановлення змісту дослідницької компетентності студентів й обранні ефективних форм, методів і засобів її формування в процесі викладання навчальної дисципліни «Клінічна лабораторна діагностика».

Матеріали та методи: нами було проведено методологічний аналіз філософської, психолого-педагогічної, методичної літератури з проблеми формування дослідницької компетентності студентів-лаборантів.

Виклад основного матеріалу. Серед провідних мотивів, які відображають спрямованість студентів на дослідницьку діяльність, ми виокремлюємо допитливість та інтерес до професії лаборанта. Серед особистісних якостей майбутнього медичного працівника-лаборанта, які сприяють його успішній професійній діяльності, особливе значення мають самостійність, ініціативність, працелюбність, готовність до творчої діяльності, цілеспрямованість та наполегливість.

Цікавим $є$ підхід, запропонований М. Голованем [7; 8], що подає модель формування дослідницької компетентності, яка містить такі компоненти: цільовий, змістовий, технологічний і результативний. Ми погоджуємося 3 думкою вченого щодо важливості формування дослідницької компетентності у здобувачів освіти та підтримуємо іiі.

Аналіз науково-педагогічної літератури $[2 ; 5 ; 6 ; 8 ; 9]$ із означеного питання дав змогу виділити такі основні компоненти дослідницької компетентності: інформаційний - уміння здійснювати бібліографічний пошук, працювати 3 книгою, довідниками та $з$ іншими першоджерелами або технічними джерелами інформації; творчий - уміння генерувати ідеї, висувати гіпотезу дослідження; вміння аналізувати, синтезувати та узагальнювати інформацію; систематизувати і класифікувати, виявляти протиріччя; здійснювати ретроспективний аналіз.

У Галузевому стандарті вищої освіти України виокремлено дослідницькі вміння, які необхідно сформувати під час навчання у ЗВО [5]. До таких умінь та навичок відносимо: здатність здійснювати пошук наукових джерел для глибшого розуміння власної досліджуваної проблеми, здатність займатися самоосвітою, вміння застосовувати набуті теоретичні знання на практиці. Зокрема, майбутні медичні лаборанти повинні володіти сучасними методиками клінічних досліджень, різними формами організації праці у сфері лабораторної діагностики, мають бути обізнані із сучасними методами виявлення патологічних процесів різних систем та органів, а також повинні вміти організовувати лабораторні дослідження відповідно до всіх нормативних вимог.

Згідно із чинною освітньо-професійною програмою підготовки за напрямом 224 «Технології медичної діагностики та лікування» навчальна дисципліна «Клініка лабораторних досліджень» передбачає формування загальнонаукової (володіти основними методами проведення клінічних досліджень) та інструментальної компетенцій (застосовувати дослідницькі навички у професійній діяльності).
Таким чином, формування дослідницької компетентності майбутніх медичних лаборантів безпосередньо пов'язане 3 розвитком дослідницьких умінь i навичок.

Як уже зазначалося вище, майбутній працівник медичної лабораторії за роки навчання в медичному закладі повинен набути досвіду дослідницької діяльності, що передбачає вміння орієнтуватися та діяти в нестандартних ситуаціях, усвідомлення важливості постійного самовдосконалення та творчої самореалізації, а також високого професіоналізму.

Під дослідницькими вміннями розуміємо комплекс усвідомлених дій, які спрямовані на чітке та ефективне виконання професійних завдань із застосуванням відповідних теоретичних знань та наукових прийомів. Під час організації освітньої діяльності студентів їх необхідно навчати планувати та організовувати вирішення поставленого завдання, визначати способи діяльності та здійснювати самоконтроль $[1 ; 6 ; 9]$. Зважаючи на вищеозначене, нами виокремлено такі вміння: навчально-організаційні, раціонального планування діяльності, навчально-інформаційні та навчально-інтелектуальні.

За компетентнісного підходу вміє вчитися той студент, який усвідомлює мету навчання, мотивований до ефективної освітньої діяльності, спроможний організувати свою навчальну діяльність, уміє відібрати потрібні знання, працює за продуманим планом, який веде до поставленої мети, вміє рефлексувати та прагне до самовдосконалення.

На нашу думку, важливо, щоб майбутній працівник лабораторії за роки навчання набув досвіду дослідницької діяльності, тобто навчився орієнтуватися та діяти в нестандартних умовах, усвідомив важливість постійного самовдосконалення та творчої самореалізації і став компетентним у своїй професії.

Неабияке значення в набутті дослідницького досвіду має студентська дослідницька робота, що несе практичне навантаження і може бути реалізованою майбутнім працівником лабораторії у своїй професійній діяльності [2 - 4]. Нами встановлено, що найкращою формою організації освітнього процесу $\epsilon$ вибір пріоритетних освітніх технологій та методів: особистісно орієнтованого, досліднииького, інтерактивного, проблемного та інформаиійно-технологічного навчання - тобто тих, які не надають готових знань, а спонукають до пошуку та в яких роль викладача зводиться до функції тьютора й організатора. Моделювання професійних ситуацій, рольові, ділові та інтелектуальні ігри, «круглі столи», тренінги, майстер-класи, мікрофон, кейс-технології тощо - це методи, що на відміну від традиційних грунтуються на активній співпраці викладача зі студентами та відповідно студентів між собою. Як наслідок - у студентів розвивається здатність колективного розв'язання складних завдань, а саме ця якість є головною вимогою до майбутніх фахівців [5]. Суб'єкти взаємодії розвивають свої дослідницькі та комунікативні навички, відповідальність, здатність працювати в команді, критичність мислення, шукаючи компроміси та відстоюючи власну думку.

В умовах компетентнісного підходу основна мета - не «навчити», а «навчити навчатися» впродовж усього життя, і таким чином сформувати компетентну особистість. Важливе завдання сучасної освіти - розвиток здатності та готовності до самоосвіти, саморозвитку, самоактуалізації й самореалізації, адже лише 
такий підхід може бути запорукою успішності майбутнього фахівця. Компетентнісний підхід зорієнтований на практичні результати, досвід особистої діяльності, вироблення ставлень, що зумовлює принципові зміни в організації навчання, яке стає спрямованим на розвиток конкретних цінностей і життєво необхідних знань і вмінь, а також професійних навичок майбутнього працівника медичної галузі [2; 9; 10].

Зважаючи на вищеозначене, при проведенні практичних занять із дисципліни «Клінічна лабораторна діагностика» варто дотримуватися такої структури:

1) етап мотивації, визначення і планування: спонукає студентів до пізнання, спільного визначення цілей заняття та очікуваних результатів, планування форм, методів діяльності, вибору тих завдань, що забезпечать актуалізацію суб'єктного досвіду, можливість самостійного здобуття знань;

2) етап вхідного діагностування рівня знань, умінь та навичок: проведення тестів, співбесіди, виконання завдань;

3) навчальний етап: вимагає засвоєння та осмислення змісту матеріалу. На цьому етапі переважає самостійна та парно-групова робота, використання активних та інтерактивних технологій. Студенти в парах та групах виконують функції викладача, застосовуючи доступний їм набір форм та методів передачі знань. Спрацьовує один із відомих принципів навчання - «навчаючи інших, навчаюся сам»;

4) етап контролю та корекції: рефлексія, оцінювання, корекція. Рефлексуються й оцінюються не лише результати, а й процеси та пов'язані 3 ним почуття (Що робив? Для чого? Що отримав у результа$m i ?$ ). 80 \% часу на такому занятті відводиться студентам, а не викладачеві.

Сучасне заняття відрізняється використанням діяльнісних методів і прийомів навчання - це, зокрема, навчальна дискусія, діалог, відеообговорення, ділові та рольові ігри, відкриті запитання, мозковий штурм тощо. Ефективним є розв'язання професійно орієнтованих ситуативних завдань, які дозволяють зорієнтуватися, як отримані знання і вміння можна застосувати в майбутній практичній діяльності та в новій ситуації. Наприклад, на практичному занятті $з$ теми «Залізодефіцитна анемія» студентами проводиться обгрунтування актуальності вивчення. Враховуючи те, що залізодефіцитні анемії - надзвичайно поширені стани, при яких знижується вміст заліза в сироватці крові, кістковому мозку та депо і таким чином порушується утворення гемоглобіну, а в подальшому й еритроцитів, унаслідок цього виникає гіпохромна анемія та трофічні розлади в тканинах. Поширеність анемії серед населення всього світу становить 24,8 \%. В абсолютних цифрах це близько 1620000000 людей, які страждають від анемії. Серед різноманітних анемічних станів доля залізодефіцитних анемій складає 80 \% [11].

Вищеозначене зумовлює навчальні цілі заняття, що передбачають ознайомлення студентів із методами дослідження, які використовуються для діагностики анемій, показаннями для їх використання, методикою проведення, діагностичною цінністю кожного 3 них. Важливо навчити студентів самостійно трактувати результати загального аналізу крові при різних варіантах анемій.

На етапі опрацювання навчального матеріалу студенти працюють 3 опорними конспектами, виконують лабораторні дослідження, передбачені навчальною програмою, а також розв'язують ситуаційні задачі.
На етапі контролю та корекції навчальної діяльності здійснюється оцінка студента за ступенем відмінності від заданого, тобто чим більше науково значущих відмінностей від відомого продукту вдається домогтися студентові, тим вищою є оцінка продуктивності його освіти. Адже що більше студент розуміє, чим він займався і чому навчився, то чіткіше і зрозуміліше може сформулювати способи своєї діяльності, проблеми, що виникають, шляхи їх розв’язання й обгрунтувати отримані результати. На нашу думку, вагомий вплив на рівень навчальної діяльності має самооцінка студента.

Під час проведення лабораторних досліджень студентам необхідно наголосити, що з метою уникнення помилок варто: використовувати пластикові або скляні пробірки, промиті перед дослідженням хлоридною кислотою та двічі - дистильованою водою; враховувати, чи вживав хворий перед дослідженням препарати заліза; пробірки при центрифугуванні слід закривати пластмасовими корками, оскільки до них може потрапити залізний пил із центрифуги; кров для досліджень брати вранці натще, оскільки існують добові біоритми коливання концентрації заліза в сироватці, а також показники заліза сироватки можуть змінюватися залежно від фаз менструального циклу. Майбутній лаборант повинен пам'ятати: уникнення неточностей у дослідженнях та помилок при діагностиці залізодефіцитної анемії призводить до якісного встановлення діагнозу та вироблення структури лікування. Студенти-лаборанти мають усвідомити, що існують лабораторні методи, застосування яких істотно підвищує верифікацію діагнозу та скорочує час діагностичних пошуків і лише комплексне оцінювання лабораторних та клінічних даних, їх усебічний аналіз дозволить встановити точний діагноз [11].

Зважаючи на те, що значна частина навчального часу в процесі вивчення дисципліни відводиться на самостійну роботу студентів, актуальним постає завдання підготовки методичного супроводу для покращення засвоєння навчального матеріалу $[1 ; 6 ; 8]$. Самостійна робота студента - це цілеспрямована діяльність, ретельно організована та проконтрольована викладачем. При цьому викладач оцінює й корегує діяльність студента щодо опрацювання наукових джерел, уміння конспектувати, складати тези або виписки. Також педагог визначає вид самостійної роботи (план, тези, виписка, конспект чи реферат), яку має виконати студент, та встановлює, де і яким чином він прозвітує про виконання завдань для самостійної роботи. Мотивуючими чинниками самостійної роботи є: широке застосування професійно орієнтованих завдань для аудиторної та позааудиторної роботи студентів; використання сучасних педагогічних технологій навчання, які поєднують науково обгрунтовані індивідуальні та колективні форми роботи; індивідуалізація навчання з урахуванням рівня підготовки та здібностей кожного студента; впровадження педагогіки співробітництва; навчання студентів організації самостійної навчальної діяльності.

Таким чином, самостійна робота - це частина освітнього процесу, яка здійснюється під керівництвом викладача та спонукає до активності, самостійності й застосування творчих здібностей студентів, а також $€$ необхідним атрибутом життєвої позиції майбутнього спеціаліста. 
Висновки. У формуванні дослідницької діяльності студентів-медиків важливу роль відіграють такі педагогічні умови, як розвиток мотивації навчання, визначення цілей та очікуваних результатів, а також використання інтерактивних технологій. Урахування визначених педагогічних умов відбувається у процесі проведення компетентнісно зорієнтованого заняття. У ході підготовки до заняття викладачеві необхідно:

- використовувати демонстраційний та дидактичний матеріал $з$ урахуванням індивідуальності кожного студента, надавати їм можливість отримувати знання самостійно під керівництвом педагога;

- застосовувати форми та методи контролю й самоконтролю навчальної діяльності студента;

- використовувати інтерактивні методики проведення заняття, що розвивають інтерес до науково-дослідницької діяльності.

Означений підхід до організації навчальної діяльності студента-медика сприяє підвищенню самооцінки та викликає бажання до самовдосконалення, що є основою формування дослідницької компетентності.

Перспективи подальших досліджень вбачаємо в застосуванні комплексу педагогічних умов щодо формування дослідницької компетентності майбутнього лаборанта клінічних досліджень, а також аналізі їх експериментальної перевірки та обгрунтуванні результатів.

\section{СПИСОК ВИКОРИСТАНОЇ ЛІТЕРАТУРИ}

1. Антонюк М. С. Психологічні особливості формування у студентів умінь і навичок самостійної роботи / М. С. Антонюк // Сучасні педагогічні технології у вищій школі : науково-методичний збірник. - К., 2005. - C. 111-113.

2. Архипова М. В. Модель формування дослідницької компетентності майбутнього інженера-педагога / М. В. Архипова // Вісник Чернігівського державного педагогічного університету. - 2010. Вип. 76. - С. 93-96. - (Серія «Педагогічні науки»).

3. Бабенко Т. П. Дослідницька діяльність студентів у контексті реформування медсестринської освіти [Електронний ресурс] / Т. П. Бабенко // Проблеми та перспективи розвитку науки на початку третього тисячоліття у країнах СНД : матеріали I Міжнар. наук.-практ. інтернет-конф. (26 - 28 лютого 2012 р.) : зб. наук. пр. Переяслав-Хмельницького держ. пед. ун-ту ім. Г. Сковороди. - Переяслав-Хмельницький, 2012. - C. 206-208. URL: http:conferences.neasmo.org. ua (дата звернення: 02.04.2019).

4. Бондаренко Л. І. Формування дослідницької компетентності майбутніх викладачів вищих навчальних закладів в умовах магістратури : автореф. дис. на здобуття наук. ступеня канд. пед. наук : спец. 13.00.04 «Теорія і методика професійної освіти» / Бондаренко Ліна Ігорівна. - Старобільськ, 2015. - 20 с.

5. Галузевий стандарт вищої освіти України (2013 р.). Освітньо-кваліфікаційна характеристика бакалавра галузі знань 1201 «Медицина», спеціальності 6.120102 «Лабораторна діагностика», кваліфікація 3221 «Лаборант (медицина)» [Електронний pecypc]. URL: http://www.testcentr.org.ua/index.php/ menu-methwork/menu-dsvo/60-smethwork/110-gsvou. html (дата звернення: 04.04.2019).

6. Гурська О. В. Основні аспекти та проблеми організації самостійної роботи студентів ВНЗ / О. В. Гурська // Матеріали Міжнародної науково-практичної конференції «Педагогіка А. С. Макаренка в полікультурному освітньому просторі» (12-14 березня 2013 р.). - Полтава, 2013. - С. 208.

7. Головань М. С. Модель формування дослідницької компетентності майбутніх фахівців у процесі професійної підготовки / М. С. Головань // Педагогічні науки: теорія, історія, інноваційні технології. 2012. - № 5 (23). - C. 196-205.

8. Головань М. С. Сутність та зміст поняття «дослідницька компетентність» / М. С. Головань, В. В. Яценко // Теорія та методика навчання фундаментальних дисциплін у вищій школі. - 2012. - Вип. VII. - С. 55-62.

9. Романишина Л. М. Формування ключових компетентностей майбутніх фахівців у процесі навчання в медичному коледжі / Л. М. Романишина, І. М. Хмеляр, М. М. Лукащук // Наукові записки. -2011. - № 2. С. 73-80. - (Серія «Педагогіка»).

10. Хмеляр I. М. Дослідницький підхід до організації навчально-виховного процесу в коледжі - умова саморозвитку студента / I. М Хмеляр // Науковий вісник Чернівецького університету : зб. наук. пр. - Чернівці : Рута, 2012. - Вип. 619. - С. 165-173. - (Серія «Педагогіка та психологія»).

11. Anemia in Pregnancy: A Pragmatic Approach / D. Sun, A. McLeod, S. Gandhi [et al.] // Obstet Gynecol Surv. - 2017. - Vol. 72 (12). - P. 730-737.

Дата надходження до редакиії: 08.04.2019 р. 